\title{
Adoption of Enterprise Resources Planning (ERP) In Indonesian Manufacturing Companies
}

\author{
Yandra Rahadian Perdana \\ Department of Industrial Engineering, Marsda Adisucipto Street No 1, 55281, Yogyakarta, Indonesia
}

\begin{abstract}
Objective - Enterprise resource planning (ERP) is a technology that supports the management of supply chain activities. ERP consists of modules that have various operational and strategic functions. The more modules that are used, the higher the adoption rate is. This study aims to examine the adoption rate based on the modules used.

Methodology/Technique - Manufacturing companies in Indonesia were selected as samples to answer the objective of this research and 155 respondents were obtained. The response from each respondent was categorised into two levels of adoption. The companies that adopted 1 to 4 modules were categorised as partial adopters, while companies that adopted five modules were considered to be full adopters.

Findings \& Novelty - This research found that 39 (25\%) companies had fully adopted the ERP modules, 24 companies (15\%) had adopted four modules, 29 companies (19\%) adopted three modules, and 26 companies (17\%) used two modules. Lastly, 37 companies (24\%) used one module. Accordingly, the dominant choice is to partially adopt the technology.

Type of Paper: Empirical.

JEL Classification: O14, 032, O33.

Keywords: Technology; Supply Chain; Enterprise Resource Planning (ERP); Adoption; Manufacturing Companies; Resource-Based View (RBV).

Reference to this paper should be made as follows: Perdana, Y.R. (2020). Adoption of Enterprise Resources Planning (ERP) In Indonesian Manufacturing Companies, J. Bus. Econ. Review, 5(3) 86-93 https://doi.org/10.35609/jber.2020.5.3(2)
\end{abstract}

\section{Introduction}

Real-time data's accuracy has consequences for decision making. The more accurate the data, the better the forecasting, replenishment, production and distribution will be (Sillanpää \& Liesiö, 2018). Technology increases the accuracy of the data's management, which in turn has a positive effect on supply chain performance (Zhang et al., 2016). Enterprise resource planning (ERP) is an automation technology using a systems approach that supports and manages information (Bintoro et al., 2015). ERP is the result of the development of information systems for material requirements planning (MRP) and MRP II.

\footnotetext{
* Paper Info: Revised: September 30, 2020

Accepted: December 31, 2020

* Corresponding author: Yandra Rahadian Perdana

E-mail: yandra.perdana@uin-suka.ac.id

Affiliation: Department of Industrial Engineering, Marsda Adisucipto Street No 1, 55281, Yogyakarta, Indonesia
} 
Information sharing activities in the supply chain become more accurate and real-time with ERP (Jacobs \& Weston, 2007). Today's business competition demands that organisations are able to acquire and utilise resources. The resource-based view (RBV) is a theory that highlights the acquisition and exploitation of tangible and intangible resources as the basis for organisational decisions (Ray et al., 2004). Hazen et al. (2016) suggested that an information system is a part of the valuable, rare, imperfectly imitable and nonsubstitutable resources, which are useful to organisations for operational support and increasing productivity. Information is the basis for supply chain planning decisions that have implications for improving organisational performance. ERP's adoption was proven to increase the organisational performance in managing information, products and financial flows (Su \& Yang, 2010).

Despite the growing attention being paid to the adoption of ERP, prior researchers (AL-Shboul, 2018; Ilin et al., 2017; Junior et al., 2019; Mayeh et al., 2016; Rajan \& Baral, 2015; Ram et al., 2014) only concerned to the antecedents and consequences of ERP's adoption, but neglected to concentrate on the level of the ERP modules' adoption. They could not explain the level of adoption in detail. On the other side, the level of ERP's adoption needs to be described in detail. Hence, this research offers an answer to the lack of literature discussing the level of adoption based on the number of ERP modules.

The remainder of this research is organised as follows. In the second section, the existing literature on ERP's adoption is reviewed as a basis to state the novelty. This is followed by Section 3 which describes the research method. Furthermore, the results of this research are described in Section 4. Then, Section 5 discusses the results of this research. Finally, the last section draws conclusions and suggests future research.

\section{Literature Review}

Barney and Clark (2007) explained that a company will not be able to gain a competitive advantage without the support of other stakeholders. The supply chain network implies an interdependent relationship (Rungtusanatham et al., 2003). This assumption is grounded on the condition that each organisation in the supply chain has specific data and information that can be exchanged and shared (Xu et al., 2014). The acquisition and utilisation of internal and external resources, in the context of RBV, means a company's strategy is to absorb knowledge and articulate it in strategic and operational decisions (Danese et al., 2013; Hitt et al., 2016). ERP is a system that promotes an integrated information management philosophy, which contributes to reducing uncertainty in the upstream and downstream supply chains. ERP's adoption includes downstream decisions, namely customer relationship management, demand management, sales promotion, and transportation. Meanwhile, upstream includes supplier relationship management, inventory management, and production scheduling (Kelle \& Akbulut, 2005; Oghazi et al., 2018).

As reflected by RBV, synchronisation is essential in supply chain management (SCM), in which each entity in the business network has complementary resources (Barney, 2012). Entities in the supply chain, such as suppliers, internal organisations, logistics service providers and customers have unique resources such as sales data, information on the availability of raw materials, production information and customer feedback (Perdana et al., 2019). The supply chain is a process chain that requires inputs, in the form of data, which are then processed into a decision (Leuschner et al., 2013). ERP is a system that integrates the data's flow and processes accurately and in real time between departments and across functions in the organisation (Davenport, 2000).

Information systems as resources become the basis for the organisation to exploit the advantages they have to compete (Wade \& Hulland, 2004). From the RBV's lens, this resource could be managed through ERP to produce accurate and real-time information that can be used to improve organisational performance (Shivam et al., 2018). The organisation needs to adopt ERP to integrate its data flow and processes accurately and in real time between departments and across functions in the supply chain network (Moe et al., 2007). ERP helps companies to operate more efficiently, effectively while integrating the business process within and 
between companies through sharing information. Ultimately, the adoption of integrated ERP aims to produce products and services that are in line with consumers' needs through the possession of resources (Seddon, 2005).

Drawing from the literature, previous research has discussed ERP's adoption. For example, Ram et al. (2014) investigated ERP's adoption and its impact on competitive advantage using proxies, e.g. system and information quality, organisational readiness, environmental assessment and strategic value. Rajan and Baral (2015) examined the impact of individual, organisational and technological characteristics on the adoption of ERP and its impact on the customer. Mayeh et al. (2016) explored the effects of absorptive capacity, communication and trust factors on the decision to adopt ERP. Ilin et al. (2017) found that ERP's adoption is driven by the relative advantages, top management's support, government resources' support and government regulatory support. AL-Shboul (2018) argued that compatibility, technology's readiness, technical barriers, top management's support, enterprise readiness, enterprise size and competitive pressure are logistical factors that have an impact on the adoption of ERP. Junior et al. (2019) identified that information sharing affected the adoption of ERP. However, previous literature ignored the level of ERP's adoption. Conceptually, ERP has five modules, the more of the complete modules that are used, the higher the adoption level is (Heizer et al., 2017). This means that the level of ERP's adoption can be identified based on the number of modules used. Thus, grounded in the RBV theory, this research attempts to fill the gap by investigating the level of adoption based on the modules that are used.

\section{Methodology}

In this research, the level of ERP's adoption is measured based on the number of modules used, namely a) production material needs management, e.g. aggregate planning, master production schedule, inventory, procurement; b) financial management; c) human resources management; d) supply chain management, e.g. e-commerce, electronic data processing, tracking and tracing; and e) customer relationships management, e.g. sales, distribution, retail (Heizer et al., 2017). The data were collected by sending an electronic mail. The respondents were selected based on the International Standard Industrial Classification (ISIC) using Indonesian statistics. The sample obtained for this research consisted of 155 respondents, selected from the 2,261 questionnaires sent out, so the response rate was 6.9\%. The answer from each respondent was categorised into two levels of adoption. The companies that adopted 1 to 4 modules were categorised as partial adopters, while companies that adopted five modules were considered to be full adopters.

\section{Results}

At this stage, the ERP modules adopted by the 155 manufacturing companies were grouped. Based on the data analysis illustrated in Table 1, it was known that only 39 (25\%) companies had fully adopted the ERP modules. Furthermore, 24 companies (15\%) had adopted four modules, while 29 companies (19\%) adopted three modules and 26 companies (17\%) used two modules. Finally, 37 companies (24\%) used one module.

Table 1. Number of ERP Module Adoptions and Types of Industry

\begin{tabular}{|c|c|c|c|c|c|c|}
\hline \multirow{2}{*}{ Industry (Manufacture of) } & \multirow{2}{*}{$\begin{array}{l}\text { Numbers of } \\
\text { Respondents }\end{array}$} & \multicolumn{5}{|c|}{ Numbers of Modules } \\
\hline & & 5 & 4 & 3 & 2 & 1 \\
\hline Processing and preserving fish, crustaceans and molluscs & 1 & & & 1 & & \\
\hline Vegetable and animal oils and fats & 3 & 1 & 1 & 1 & & \\
\hline Dairy products & 2 & 1 & & 1 & & \\
\hline Other food products & 8 & 4 & & & & 4 \\
\hline Prepared animal feeds & 2 & 1 & 1 & & & \\
\hline Beverages & 4 & & 1 & 1 & 1 & 1 \\
\hline
\end{tabular}

J. Bus. Econ. Review 5 (3) 86 - 93 (2020) 


\begin{tabular}{|c|c|c|c|c|c|c|}
\hline \multirow{2}{*}{ Industry (Manufacture of) } & \multirow{2}{*}{$\begin{array}{l}\text { Numbers of } \\
\text { Respondents }\end{array}$} & \multicolumn{5}{|c|}{ Numbers of Modules } \\
\hline & & 5 & 4 & 3 & 2 & 1 \\
\hline Tobacco products & 2 & 1 & & & 1 & \\
\hline Wearing apparel, except fur apparel & 10 & 3 & 1 & 2 & 3 & 1 \\
\hline Leather and related products, included artificial leather & 1 & & & & 1 & \\
\hline Footwear & 10 & 5 & 1 & & 1 & 3 \\
\hline Paper and paper products & 2 & & & & 2 & \\
\hline Printing and service activities related to printing & 1 & & & 1 & & \\
\hline Coke oven products & 8 & 1 & 1 & 2 & 2 & 2 \\
\hline Refined petroleum products & 1 & & & 1 & & \\
\hline Chemicals & 18 & 5 & 4 & 2 & 1 & 6 \\
\hline Other chemical products & 4 & 3 & & & & 1 \\
\hline Pharmaceuticals, medicinal chemical and botanical products & 4 & & 2 & 1 & 1 & \\
\hline Rubber product & 3 & & 1 & 1 & & 1 \\
\hline Plastics products & 3 & 1 & 1 & 1 & & \\
\hline Non-metallic mineral products n.e.c. & 5 & & & 2 & & 3 \\
\hline Basic iron and steel & 5 & 2 & 1 & 1 & & 1 \\
\hline Basic precious and other non-ferrous metals & 1 & & & 1 & & \\
\hline $\begin{array}{l}\text { Structural metal products, tanks, reservoirs and steam } \\
\text { generator }\end{array}$ & 1 & 1 & & & & \\
\hline $\begin{array}{l}\text { Other fabricated metal products and metalworking service } \\
\text { activities }\end{array}$ & 8 & 1 & & 1 & 3 & 3 \\
\hline Computers and peripheral equipment & 9 & 1 & 2 & 2 & 1 & 3 \\
\hline $\begin{array}{l}\text { Electrics motors, generators, transformer, electricity } \\
\text { distribution and control apparatus }\end{array}$ & 1 & & & 1 & & \\
\hline Wiring and wiring devices & 2 & 1 & 1 & & & \\
\hline Domestic appliance & 1 & 1 & & & & \\
\hline Special purpose-machinery & 6 & & 2 & & 2 & 2 \\
\hline Motor vehicles & 8 & 1 & & 2 & 3 & 2 \\
\hline Transport equipment n.e.c & 17 & 4 & 3 & 4 & 4 & 2 \\
\hline Musical instruments & 1 & 1 & & & & \\
\hline Medical and dental instruments and supplies & 3 & & 1 & & & 2 \\
\hline Total & 155 & 39 & 24 & 29 & 26 & 37 \\
\hline
\end{tabular}

\section{Discussion}

As can be seen in Table 1, the level of ERP's adoption by Indonesian manufacturing companies is not that extensive; the majority of them are partial adopters. Accordingly, this result indicates that Indonesia has weak systems' integration, as shown by the low level of companies categorised as full adopters. One possible explanation, Indonesia, as a developing country, is characterised by the uncertainty of their governments' support, weak technology infrastructure, trust, culture and organisational commitment, which makes ERP's adoption difficult. In practical terms, the prerequisites for ERP's adoption are easier for organisations to fulfil in developed countries (Zhenyu \& Prashant, 2001). Thus, it can be assumed that behavioural factors are the keys to adopting ERP in Indonesia. The argument of this proposition is that ERP is more than a tool; it is related to human behaviour interacting in a system. Mahmood et al. (2019) stated that ERP's adoption requires the availability of high quality technology, infrastructure and management's support. ERP demands a readiness from organisations to change their behaviour to a new standard, with more effective and efficient ways (Abdinnour-Helm et al., 2003). Grounded in the literature, there is a relationship between organisations in developing countries and ERP's adoption. For example, Mahendrawathi et al. (2018) stated that ERP's 
implementation requires rule-abiding behaviour and emphasises standard operating procedures. This situation shows that when deciding to adopt ERP, the internal and external entities of the organisation need to change their behaviour.

Barratt (2004) explained the problems that are faced by companies in the supply chain. First, there is a lack of company awareness regarding the cross-functional relationships within the departments of the company. Furthermore, there is a tendency for each department of the company to make silo decisions. Lastly, the company does not have valid and reliable information, which causes the failure of product promotions, low sales and high inventory levels. Mayeh et al. (2016) stated that ERP's adoption requires the sharing of data from internal and external organisations; this data exchange process requires mutual trust. Kamdjoug et al. (2020) explained that there is a sense of concern if one of the parties in the supply chain misuses the data and exploits the others' interests. Also, the asymmetry of interests poses a challenge to ERP's adoption. Therefore, it is necessary to align the perspectives between the internal and external organisations when deciding on ERP's adoption. Each company has different business processes, so it is necessary to match the existing resources with the adoption plan for ERP (Ngai et al., 2008).

If adopted properly, ERP can increase a company's ability to mitigate its supply chain uncertainty. The flow of data and information are more rapidly analysed and translated into the right decisions, so that organisations have better performance (Gallagher \& Gallagher, 2012). ERP relies on the integration of resources between internal organisations, suppliers, distributors and consumers, where decisions can have a positive impact on the supply chain's performance. The essence of ERP's adoption is the management of resources through bundling, such as data, information and knowledge, to create valuable decisions for users or customers (Reyes et al., 2015).

Borrowing from the SCM's perspective, resource management emphasises the elimination of non-valueadded activities to each process in the ERP. The information produced by various ERP modules becomes an input for decision-makers to determine a more effective and efficient process in the supply chain (Ram et al., 2013). For example, one of the purchasing department's functions is to acquire raw materials at the right prices, of the right quality and in the right quantity, in accordance with the company's strategy. This information will help organisations in managing their inventories. Also, the distribution department can schedule the delivery of goods by considering vehicle availability, the optimal route, and tracking and tracing. Therefore, ERP becomes an operational form of integration through the easy access, transfer and utilisation of data, information and knowledge (Acar et al., 2017).

Taking all this into consideration, manufacturing companies in Indonesia need to increase the level of their adoption of ERP. This research argues that ERP, as an information system, facilitates the exchange of data and information that is connected to modules. Each module has a specific function, so the more modules that are adopted, the adopting organisation gains a clearer and more complete picture of the desired process. The more complete the implementation of the ERP modules are, the more integrated the supply chain system is. Grounded in RBV, the adoption of ERP modules can be viewed as the possession of resources, namely information systems, which are organisational capital to use to compete with. Hence, the full adoption of ERP becomes a proxy for organisations to process their resources in more effective and efficient ways, to create a competitive advantage.

\section{Conclusion}

This research aims to identify the level of ERP's adoption based on the number of modules used by manufacturing companies in Indonesia. Using the RBV's perspective, this research shows that ERP has only been partially adopted by 116 companies; the rest have fully adopted it. The findings from this research certainly need to be of concern to practitioners, especially manufacturing companies in Indonesia to improve the level of ERP's adoption. The adoption of ERP requires synergy between the functions, both within and 
external to the organisation. It should be emphasised that, at this time, a business is a chain of processes that involves stakeholders such as suppliers, producers, logistics service providers and consumers. Each stakeholder plays a critical role that influences the others. Obstacles to one of the stakeholders can interfere with the process chain from upstream to downstream. Hence, the integration of the data, information and decisions between the internal and external organisations are essential. In accordance, ERP assists the supply chain integration.

Using the RBV assumption, ERP can be the basis for the formulation of precise tactics to increase the economic value of the product or service. Consequently, the capabilities of the organisation are needed to exploit the information generated by ERP and convert it into knowledge, which is a source of a sustainable competitive advantage. Resources such as data, information and knowledge can only be assets for gaining an advantage if the company has a system of planning, implementing and evaluating the use of resources through ERP. Consequently, information sharing is an essential requirement for the adoption of ERP, which is valuable for strategic and tactical decision-making in the supply chain. ERP, as an integrated system, becomes an intermediary for synchronising the information flow from upstream to downstream and vice versa.

The benefit of a fully integrated ERP is that it will minimise the limitations in organisational decisionmaking in the supply chain such as planning, implementation and supply chain control. However, there is an important note to ERP's adoption, namely the availability of resources and the full support of the management. Organisational factors such as the management's commitment, the availability of ICT infrastructure, financial support and the culture may be reasons for the low adoption of ERP in a fully integrated Indonesia. Therefore, further research can explore, in more depth, the causes of the low adoption rate of ERP modules in Indonesia.

\section{References}

Abdinnour-Helm, S., Lengnick-Hall, M. L., \& Lengnick-Hall, C. A. (2003). Pre-implementation attitudes and organizational readiness for implementing an enterprise resource planning system. European journal of operational research, 146(2), 258-273. https://doi.org/10.1016/S0377-2217(02)00548-9

Acar, M. F., Tarim, M., Zaim, H., Zaim, S., \& Delen, D. (2017). Knowledge management and ERP: Complementary or contradictory? International Journal of Information Management, 37(6), 703-712. https://doi.org/10.1016/j.ijinfomgt.2017.05.007

Moh'd Anwer, A. S. (2019). Towards better understanding of determinants logistical factors in SMEs for cloud ERP adoption in developing economies. Business Process Management Journal. https://doi.org/10.1108/BPMJ-01-20180004

Barney, J. B. (2012). Purchasing, supply chain management and sustained competitive advantage: The relevance of resource-based theory. Journal of supply chain management, 48(2), 3-6.https://doi.org/10.1111/j.1745493X.2012.03265.X

Barney, J. B., \& Clark, D. N. (2007). Resource-based theory: Creating and sustaining competitive advantage. Oxford University Press on Demand.

Barratt, M. (2004). Understanding the meaning of collaboration in the supply chain. Supply Chain Management: an international journal. http://dx.doi.org/10.1108/13598540410517566

Bintoro, B. P. K., Simatupang, T. M., Putro, U. S., \& Hermawan, P. (2015). Actors' interaction in the ERP implementation literature. Business Process Management Journal. https://doi.org/10.1108/BPMJ-11-2013-0142

Danese, P., Romano, P., \& Formentini, M. (2013). The impact of supply chain integration on responsiveness: The moderating effect of using an international supplier network. Transportation Research Part E: Logistics and Transportation Review, 49(1), 125-140.https://doi.org/10.1016/j.tre.2012.08.002

Davenport, T. H. (2000). Mission critical: realizing the promise of enterprise systems. Harvard Business Press.

Gallagher, K. P., \& Gallagher, V. C. (2012). Organizing for post-implementation ERP. Journal of Enterprise Information Management.https://doi.org/10.1108/17410391211204400 
Hazen, B. T., Skipper, J. B., Ezell, J. D., \& Boone, C. A. (2016). Big data and predictive analytics for supply chain sustainability: A theory-driven research agenda. Computers \& Industrial Engineering, 101, 592-598. https://doi.org/10.1016/j.cie.2016.06.030

Heizer, J., Render, B., \& Munson, C. (2008). Operations management. Prentice-Hall.

Hitt, M. A., Xu, K., \& Carnes, C. M. (2016). Resource based theory in operations management research. Journal of Operations Management, 41, 77-94. https://doi.org/http://dx.doi.org/10.1016/j.jom.2015.11.002

Ilin, V., Ivetić, J., \& Simić, D. (2017). Understanding the determinants of e-business adoption in ERP-enabled firms and non-ERP-enabled firms: A case study of the Western Balkan Peninsula. Technological Forecasting and Social Change, 125, 206-223.https://doi.org/10.1016/j.techfore.2017.07.025

Jacobs, F. R. (2007). Enterprise resource planning (ERP)—A brief history. Journal of operations management, 25(2), 357-363. https://doi.org/10.1016/j.jom.2006.11.005

Junior, C. H., Oliveira, T., \& Yanaze, M. (2019). The adoption stages (Evaluation, Adoption, and Routinisation) of ERP systems with business analytics functionality in the context of farms. Computers and Electronics in Agriculture, 156, 334-348. https://doi.org/10.1016/j.compag.2018.11.028

Kamdjoug, J. R. K., Bawack, R. E., \& Tayou, A. E. T. (2020). An ERP success model based on agency theory and IS success model. Business Process Management Journal.https://doi.org/10.1108/BPMJ-04-2018-0113

Kelle, P., \& Akbulut, A. (2005). The role of ERP tools in supply chain information sharing, cooperation, and cost optimization. International journal of production economics, 93, 41-52. https://doi.org/https://doi.org/10.1016/j.ijpe.2004.06.004

Leuschner, R., Rogers, D. S., \& Charvet, F. F. (2013). A meta-analysis of supply chain integration and firm performance. Journal of Supply Chain Management, 49(2), 34-57.https://doi.org/10.1111/jscm.12013

Mahendrawathi, E. R., Hanggara, B. T., \& Astuti, H. M. (2019). Model for BPM implementation assessment: evidence from companies in Indonesia. Business Process Management Journal. https://doi.org/10.1108/BPMJ-08-2016-0160

Mahmood, F., Khan, A. Z., \& Bokhari, R. H. (2019). ERP issues and challenges: a research synthesis. Kybernetes. https://doi.org/10.1108/K-12-2018-0699

Mayeh, M., Ramayah, T., \& Mishra, A. (2016). The role of absorptive capacity, communication and trust in ERP adoption. Journal of Systems and Software, 119, 58-69.https://doi.org/10.1016/j.jss.2016.05.025

Moe, C. E., Fosser, E., Leister, O. H., \& Newman, M. (2007). How can organizations achieve competitive advantages using ERP systems through managerial processes?. In Advances in Information Systems Development (pp. 37-46). Springer, Boston, MA. https://doi.org/10.1007/978-0-387-70761-7_4

Ngai, E. W., Law, C. C., \& Wat, F. K. (2008). Examining the critical success factors in the adoption of enterprise resource planning. Computers in industry, 59(6), 548-564.https://doi.org/10.1016/j.compind.2007.12.001

Oghazi, P., Rad, F. F., Karlsson, S., \& Haftor, D. (2018). RFID and ERP systems in supply chain management. European Journal of Management and Business Economics. https://doi.org/10.1108/EJMBE-02-2018-0031

Perdana, Y. R., Ciptono, W. S., \& Setiawan, K. (2019). Broad span of supply chain integration: theory development. International Journal of Retail \& Distribution Management. https://doi.org/10.1108/IJRDM-03-2018-0046

Rajan, C. A., \& Baral, R. (2015). Adoption of ERP system: An empirical study of factors influencing the usage of ERP and its impact on end user. IIMB Management Review, 27(2), 105-117. https://doi.org/10.1016/j.iimb.2015.04.008

Ram, J., Corkindale, D., \& Wu, M. L. (2014). ERP adoption and the value creation: Examining the contributions of antecedents. Journal of Engineering and Technology Management, 33, 113-133. https://doi.org/10.1016/j.jengtecman.2014.04.001

Ram, J., Corkindale, D., \& Wu, M. L. (2013). Implementation critical success factors (CSFs) for ERP: Do they contribute to implementation success and post-implementation performance?. International Journal of Production Economics, 144(1), 157-174.https://doi.org/10.1016/j.ijpe.2013.01.032

Ray, G., Barney, J. B., \& Muhanna, W. A. (2004). Capabilities, business processes, and competitive advantage: choosing the dependent variable in empirical tests of the resource-based view. Strategic management journal, 25(1), 2337. https://doi.org/10.1002/smj.366

Reyes, P. M., Worthington, W. J., \& Collins, J. D. (2015). Knowledge management enterprise and RFID systems. Management Research Review. https://doi.org/10.1108/MRR-01-2013-0011 


\section{Yandra Rahadian Perdana}

Choi, T. Y. (2003). Supply-chain linkages and operational performance. A resource-based-view perspective. International Journal of Operations \& Production Management, 23(9), 10841099.https://doi.org/10.1108/01443570310491783

Seddon, P. B. (2005). Are ERP systems a source of competitive advantage?. Strategic Change, 14(5), $283-293$. https://doi.org/https://doi.org/10.1002/jsc.729

Gupta, S., Kumar, S., Singh, S. K., Foropon, C., \& Chandra, C. (2018). Role of cloud ERP on the performance of an organization. The International Journal of Logistics Management.https://doi.org/10.1108/IJLM-07-2017-0192

Sillanpää, V., \& Liesiö, J. (2018). Forecasting replenishment orders in retail: value of modelling low and intermittent consumer demand with distributions. International Journal of Production Research, 56(12), 4168-4185. https://doi.org/10.1080/00207543.2018.1431413

Su, Y. F., \& Yang, C. (2010). Why are enterprise resource planning systems indispensable to supply chain management?. European Journal of Operational Research, 203(1), 81-94. https://doi.org/10.1016/j.ejor.2009.07.003

Wade, M., \& Hulland, J. (2004). The resource-based view and information systems research: Review, extension, and suggestions for future research. MIS quarterly, 28(1), 107-142. https://doi.org/10.2307/25148626

Xu, D., Huo, B., \& Sun, L. (2014). Relationships between intra-organizational resources, supply chain integration and business performance. Industrial Management \& Data Systems. https://doi.org/10.1108/IMDS-05-2014-0156

Zhang, X., Van Donk, D. P., \& van der Vaart, T. (2016). The different impact of inter-organizational and intraorganizational ICT on supply chain performance. International Journal of Operations \& Production Management. https://doi.org/10.1108/IJOPM-11-2014-0516

Huang, Z., \& Palvia, P. (2001). ERP implementation issues in advanced and developing countries. Business process management journal.https://doi.org/10.1108/14637150110392773 